MAKHYNIA Nataliya Volodymyrivna, $\mathrm{PhD}$ in Pedagogics, associate professor at foreign languages department, Cherkasy State Technological University e-mail: natalymakhynia@gmail.com https://orcid.org/0000-0001-8641-6602

\title{
CURRENT TENDENCIES OF ADULT EDUCATION IN EU BASED ON THE CONCLUSIONS OF EAEA'S COUNTRY REPORT
}

The basic principles of organization of educational environment in adult learning are determined. The differences between the planning of educational practices for children and teenagers and adult learners are outlined. It was found out that the main principles for formation and management of educational environment in adult learning are: the formation of mutual respect, trust and support; creation of mechanisms of mutual planning; diagnostics of the needs of adults involved in the educational process; transforming the need into the purpose; formation of an educational activity type and its management; assessing the level of achievement of the set learning goal.

Key words: adult education, lifelong learning, formal education, informal education, international program, umbrella organization, European Association for the Education of Adults, international cooperation.

Introduction. Quick and unstoppable development of new technologies requires constant mobilization of forces and opportunities for learning and acquiring more and more skills. Knowledge is currently the center of activity and development of individuals and society in general. It is personal capital, special means to achieve success in life. Constant, continuous education promotes a deeper understanding of events and processes that prevent unemployment, humiliation and discrimination.

Adult education is an integral part of lifelong learning. The rich history of adult education in Europe varies greatly by region and carries powerful elements of Enlightenment equity and access thinking. Recognition of adult learning has been grown since the midnineties. It is vitally important to the European Social Model and to the standing of a strong Europe in globally competitive world [10].

Statistics data demonstrate the necessity of adult education in European Union. According to it, one in four adults in Europe has completed lower secondary education at most - differences between countries and age groups are significant. Around $25 \%$ of adults (25-64) in the EU - that is around 70 million people - have not completed any formal education beyond the level of lower secondary education. Of these, around 20 million adults $(6.5 \%$ of adults in the EU) left the education system with no more than primary education. Southern European countries are the most affected by low levels of educational attainment among the adult population. Young adults have on average a significantly higher educational attainment level than the older population [5].

Adult education is the type of education that is free from rigidity (systems that are very strict or difficult to change) with regards to curriculum, learning materials, methodology, venue, duration or the length an individual takes to complete a particular instructional session [11]. Adult learn in a variety of ways. Therefore, it stands to reason that there are a variety of educational delivery formats and teaching methods that should be employed to facilitate the learning process of adults.

European Association for the Education of Adults (EAEA) is the voice of non-formal adult education in Europe. EAEA is a European NGO with 142 member organizations in 44 
countries and represents more than 60 million learners Europe-wide. EAEA promotes adult learning and access to and participation in non-formal adult education for all, particularly for groups currently under-represented. EAEA's main roles are:

$\checkmark$ policy advocacy for lifelong learning at European level;

$\checkmark$ development of practice through projects, publications and training;

$\checkmark$ provision of information and services for our members;

$\checkmark$ international cooperation [1].

Participation in adult education and training is determined by several factors, in particular educational attainment, employment status, occupational category, age and skills: adults with low level or no qualifications, those in low-skilled occupations, the unemployed and economically inactive, older people and the least skilled, are less likely to participate in lifelong learning. In other words, the adults most in need of education and training are those with the least access to lifelong learning opportunities.

The purpose of the paper presented is to identify the main trends in the sector of European adult education based on the annual reports of EAEA [4].

Presentation of key material. The annual report is based on a survey sent to EAEA's members, asking them about the state of adult education in their country. The views expressed come from a variety of contexts. EAEA members are often umbrella organizations representing their country's adult education providers, and can have the status of a non-governmental organization representing providers to the national or regional government.

The focus of work may be on research in adult education, or more oriented towards policy advocacy. Some members work on a local level as adult educators, and their work may focus on a particular sub-area of adult education such as basic skills provision or vocational training. Through the survey, these national, regional or local organizations share the knowledge they have gathered about the state of adult education in their country throughout their own work within this field. In addition to this insight gathered over time, they could also consult providers within their network and reflect their views in the survey responses. In some countries the report is based on the account of one EAEA member; the national representativeness of the views expressed may thus vary depending on the geographic reach of each participating organization within their country, the level on which they mainly operate (as national institutions, NGO umbrella organizations, regional or local providers), and the extent of consultation they conducted before responding to the survey. There are some trends that can be perceived when reading this report:

The impact of European and international adult education policies. A specific characteristic of the survey in 2017 was asking the members about the impact different EU and international policies and strategies have on their work. The main programs involved are:

$\checkmark$ European Agenda for Adult Learning (2011) [6];

$\checkmark$ Upskilling Pathways (2016) [7];

$\checkmark$ The United Nations' Sustainable Development Goals (2015), and particularly Goal 4, "Ensure inclusive and equitable quality education and promote lifelong learning opportunities for all" [13].

Many EAEA members highlight various initiatives to implement the European Agenda in their country, be it at the national level or by civil society organizations.

Several members (in Germany, the Netherlands) note that the European Agenda for Lifelong Learning is a useful tool for advocating for adult education. Referring to this document allows them, as practitioners or as regional or national representatives of practitioners, to influence education policies and strategies within their country.

Several members (in Sweden, Austria, French-speaking Belgium) also highlight a kind of tension in the impact European or national adult education policies have on their work: policies set certain standards for adult education, which allows this field to be better recognized. At the same time, having external standards for providers' work "formalizes" adult 
education, making it less non-formal although historically this has been an important component of adult education in many countries. In other words, formalization brings the challenge of limiting providers' autonomy to choose the contents of the teaching they provide.

The Upskilling Pathways strategy will be a key document for the adult education sector in the next few years. It intends to provide basic skills training - supported by skills assessments and validation and recognition - to many Europeans. The EU member states are currently meant to identify their key target groups for this initiative and come up with an implementation plan. Taking into account that Upskilling Pathways is a relatively recent policy (December 2016), most EAEA members responding to the survey noted that its effects are not yet noticeable within their work.

Key topics: refugees and engaging new learners. Many EAEA members continue working with refugees, and while language training remains one of the key issues, new areas are now becoming important: vocational training, family learning, civic education and intercultural learning with the host communities. In parallel and complement to the European Commission's Upskilling Pathways strategy, many members are keen to engage new learners and make adult education more accessible and attractive for disadvantaged groups [1].

Support for adults with low basic skills or low level qualifications is now commonly integrated into countries' policy agendas, often as a part of education and training policies. In this context, a few countries have issued strategies referring specifically to adult literacy and basic skills. Beyond the educational sector, central authorities provide explicit support for access to skills and qualifications within their economic reforms or, more specifically, their employment strategies. Furthermore, countries tend to pay specific attention to groups where the lack of skills and qualifications may be of particular concern, namely the unemployed, young people, older workers, immigrants or ethnic minorities.

Despite the fact that policy documents commonly include explicit references to promoting access to education and training for various vulnerable groups of learners, they rarely refer to definite objectives and targets to be reached. Therefore, even when evaluation processes are in place, they do not necessarily address the most important issues affecting adults with low basic skills or low level qualifications. This raises the question of whether countries' strategies and policy agendas have a real potential to enhance lifelong learning opportunities for low-qualified adults and other vulnerable groups. The area deserves further investigation [2].

National Qualification Frameworks and Validation. A number of countries are working on validation and the development or implementation of National Qualifications Frameworks.

Validation is the formal recognition of the results of non-formal education and informal learning. Reactions to these developments vary across the EAEA membership: many members welcome the opportunities that NQFs provide but others remain sceptical about its restrictions: they can limit the freedom of non-formal adult education providers to choose the contents of the teaching they provide, if all teaching contents need to be aligned with specific outcomes in terms of qualifications.

EAEA and its members have done considerable work when it comes to validation and have also put together a number of recommendations on how to implement NQFs and validations systems that would put non-formal adult education at equal footing with formal education, put the learner at the center and avoid a formalization of the non-formal.

A more comprehensive approach to adult education is necessary. A number of EAEA members think that adult education in their countries (or at least the public support for it) is too limited. In some countries, it might be a strong focus on basic skills, in others on employment related training.

Some EAEA members (Austria, Greece) highlight the importance of democracy education: raising more awareness about democratic principles and institutions and fostering 
critical thinking. EAEA members are therefore supporting an adult education approach that comprises and supports the different sectors of adult education: from basic skills to VET, civic education and active citizenship, personal development and liberal adult education [1].

In all countries there are opportunities for adults to achieve a recognized qualification during adulthood; however, the proportion of adults who have completed a medium-level qualification later in life varies between countries.

Most European countries have invested in developing vocational qualification systems that allow access for adults with limited prior formal learning. These may represent the first stepping-stone towards higher qualifications.

Countries use various approaches to delivering general or vocational upper secondary qualifications to adult learners: some have established a standalone program framework described as 'adult upper secondary education', while others have developed a framework for adults that covers several levels of qualifications. In contrast, a number of countries deliver upper secondary programs open to adults within their mainstream upper secondary education and training system.

On average, $3.6 \%$ of adults in Europe have achieved an upper secondary qualification during adulthood (i.e. aged 25 or above). Yet, there are significant differences between countries, ranging from around $12 \%$ to less than $1 \%$ [5].

Visibility and recognition of the sector. A common challenge for adult education providers across Europe is raising awareness about the value of their field:

1) making policymakers but also citizens more aware of what adult education is and what its benefits are;

2) making the field better known and better supported.

This is especially important in countries where participation in adult education is low, where the field is not well-known by politicians or citizens and has little financial means. Indeed, funding remains a key challenge for many EAEA members. Advocating for adult education is also considered important in countries in which adult education is already largely recognized and receives funding from the government. EAEA members from such countries often note that governmental funding is insufficient to cover needs, and that education does not reach the most disadvantaged segments of the population. Advocacy towards policymakers and raising awareness within the general population therefore remain important.

Conclusion. EAEA's country reports outline developments in adult education in different European countries, giving insight into the state of adult education across Europe and allowing comparisons between countries. Over the past few years, this publication has become an established tool for advocacy and policymaking at the European level, and it aims to complement reporting published by the European Commission.

The report is based on a survey sent to EAEA's members, through which members can express their views about adult education in their country. The national representativeness of the views expressed may thus vary depending on members' geographic reach, the level on which they operate and the extent of consultation they conducted before responding to the survey.

The report offers a civil society view, drawing from EAEA's vast network. It gives professionals working in adult education across Europe a platform to express their perspective on the field and the possibility to relay learners' views. The report thus bridges the gap between citizens involved in adult education and EU institutions creating adult education policies.

Given the publication of major policy and strategy documents in recent years, such as the Upskilling Pathways and the 2030 Agenda for Sustainable Development, an important focus of the survey EAEA conducted this year was asking our members about the impact of these initiatives on their work. This year's country reports have thus focused on the links 
between national adult education provision and broader European and international policy/strategy contexts.

Additionally, the European Agenda for adult learning has now been in place since 2011 and its impact can now be verified in this report. Although priorities for the coming year vary between members and countries, a point highlighted by numerous members is the importance of raising awareness about non-formal adult education: making the field better known among policymakers and potential learners, but also ensuring its current support is maintained in countries where the sector already receives governmental support.

The reports of this kind help to have a better understanding of recent developments in adult education across Europe.

\section{References.}

1. Adult Education in Europe 2017 - A Civil Society View (2017) Publisher: European Association for the Education of Adults - EAEA. - 64 p.

2. Adult Education Trends and issues in Europe: Documentation of activities. - Restricted tender № EAC/43/05 as completed by $11^{\text {th }}$ of August 2006.

3. Daines, J. Adult Learning. Adult Teaching. $3^{\text {rd }}$ Edition. - Welsh Academic Press, Cardiff, 2009. -136 p.

4. http://www.eaea.org/en/projects/eaea-coordinated-projects/ava.html

5. European Commission/EACEA/Eurydice, 2015. Adult Education and Training in Europe: Widening Access to Learning Opportunities. Eurydice Report. Luxembourg: Publications Office of the European Union.

6. European Council (2011), "Council Resolution on a renewed European agenda for adult learning. 2011/C $372 / 01$ ", in Official Journal of the European Union, available on: http://eur-lex.europa.eu/legalcontent/EN/TXT/?qid=1501756608119\&uri=CELEX:32011G1220(01).

7. European Council (2016), "Council Recommendation of 19 December 2016 on Upskilling Pathways: New Opportunities for Adults (2016/C 484/01)", in Official Journal of the European Union, available on: http://eur-lex.europa.eu/legal-content/EN/TXT/?qid=1501757293132\&uri=CELEX:32016H1224(01).

8. Eurostat. The Life of women and men in Europe, A statistical portrait, 197 pages, ISBN 92-894-3569-2, EUR 30.

9. Merriam, S. Perspectives on adult learning: framing our research. Retrieved from: http://www.edst.educ.ubc.ca/aerc/1999/99caffarella.htm

10. Mohanty. S. (2012) Adult and Non-Formal Education. Second Edition, Deep \& Deep Publications Pvt. Ltd.

11. Tuijnman A.C. International Encyclopedia of Adult Education and Training. Oxford : Pergamon Press, 2013. $156 \mathrm{p}$.

12. How teachers change: A study of professional development in adult education : Report 25a / C. Smith, J. Hofer, M. Gillespie, M. Solomon, K. Rowe. Cambridge, MA : National Center for the Study of Adult Learning and Literacy, 2013.

13. United Nations (2015), "Resolution adopted by the General Assembly on 25 September 2015. 70/1. Transforming our world: the 2030 Agenda for Sustainable Development", available on: http://www.un.org/ga/search/view_doc.asp?symbol=A/RES/70/1\&Lang=E.

\section{МАХИНЯ Наталія Володимирівна,}

кандидат педагогічних наук, доцент, доцент кафедри іноземних мов, Черкаський державний технологічний університет

\section{СУЧАСНІ ТЕНДЕНЦІЇ ОСВІТИ ДОРОСЛИХ У ЄВРОСОЮЗІ НА ОСНОВІ ЩОРІЧНОГО ЗВІТУ СВРОПЕЙСЬКОЇ АСОЦІАЦЇ̈ ОСВІТИ ДОРОСЛИХ}

Вступ. Освіта дорослих - тип навчання, не обмежений суворими організаційними рамками, вільний у виборі навчальних матеріалів, методології, місия проведення занять, тривалості курсу. Дорослі навчаються багатьма способами. Відповідно, існує багато форматів та методів навчання, які можуть сприяти освітнім результатам дорослих учнів.

Мета. Стаття спрямована на проведення аналізу основних принципів формування ефективного навчального середовища і управління ним під час організації освіти дорослих.

Результати. Поняття освіти дорослих розглядають як неперервний процес навчання упродовж життя, що базується на потребі набуття нових знань та умінь. Оскільки навчання $\epsilon$ процесом соціальним, людина здобуває освіту з трьох причин: для самовдосконалення; для більшої конкурентноспроможності на ринку прачі (робоча зайнятість, краща зарплата, кар'єра, вимоги роботодавия, набуття нових компетенцій); для кращих можливостей у 
суспільному житті (емпатія, толерантність, прийняття рішень, захист навколишнього середовища - ці питання вимагають колективних рімень, $i$ люди прагнуть долучатися, висловлювати власну думку, впливати на громадські рішення).

У освітніх колах триває дискусія про значну різницю в андрагогічних $i$ педагогічних принципах навчання. Завдання андрагога є подвійним: по-перше, створити ефективне навчальне середовище для дорослого учня, у якому б він отримував максимальну підтримку своӥх навчальних прагнень; по-друге, слугувати для дорослого учня надійним джерелом інформації, при цзьому спрямовуючи його до інших джерел знань та навчальних ресурсів: колег, фахівців, керівників, літератури, тощьо. У процесі формування навчального середовища, андрагог має справу з різними завданнями, відмінними від завдань педагога. Тоді як педагог за основне завдання має передачу знань учням, андрагог радше сприяє набуттю нових знань слухачем.

Організовуючи прочес навчання, андрагог має подбати про такі елементи: 1) Формування клімату, щзо $е$ важливою умовою ефективного набуття знань. Клімат формується у двох категоріях - інституційній і ситуативній. Почуття поваги - важливий чинник ефективного клімату освітнього середовища. 3 іншого боку, зневага $i$ неповага відвертає учнів від процесу набуття знань і спрямовує їхній навчальний потенціал деінде. 2) Створення можливості для спільного планування навчальної діяльності. Людина позитивно ставиться до того виду діяльності, який вона сама спланувала або ж взяла участь у його попередньому обговоренні. 3) Діагностика навчальних потреб дорослого учня. У цзьому процесі андрагог може також використати потенціал інституцій, організацій чи громади. Установлення адекватних потреб слухачів допомагає ставити правильні навчальні иілі програм навчання. 4) Перетворення навчальних потреб у навчальні иілі - напрями освітнього розвитку особистості. 5) Формування $і$ управління навчальною діяльністю дорослих учнів. Після постановки навчальних цілей, андрагог і учасники прочесу навчання мають спланувати шляхи їх досягнення. Сюди входить визначення ресурсів для досягнення иілей та вибір ефективних стратегій для використання циих ресурсів. 6) Оцінка досягнення результатів навчання. Освітні інституиії часто для такого оцінювання застосовують кількісні показники. У новітніх тенденціях - акцент на якісних показниках: оцінка того, як змінюється реакція учня на реальні життєві ситуачії, кейси, практичні завдання. Андрагогічна модель навчання, крім того, вимагає, щуоб учень був також залучений у процес оцінювання навчальних результатів.

Висновки. Навчання дорослих учнів буває особливим, складним, нетрадиційним. Зазвичай андрагог має справу з учнем, який володіє власним досвідом у навчанні, тому інтенсивність залучення слухача у навчання сприятиме набуттю ними нових знань і умінь. Залучення дорослого учня у прочес планування навчального процесу $і$ оцінювання набутих ним знань $\epsilon$ необхідним елементом побудови ефективної моделі навчання дорослих.

Ключові слова: освіта дорослих, освіта упродовж життя, формальна освіта, неформальна освіта, міжнародна програма, головна організація, Європейська асочіачія освіти дорослих, міжнародна взаємодія.

Одержано редакиією 17.10.2018 p. Прийнято до публікаичї 21.10.2018 p. 